原著

超選択的肝動脈造影法と血管内カテーテル留置法の工夫

東邦大学第 1 外科（主任：吉雄敏文教授）

渡邊 正志 前田 利道 中崎 晴弘

巾秀俊蔵本新太郎吉雄 敏文

肝癌の診断, 治療において超選択的肝動脈造影法や肝動脈内カテーテルの留置法は, 臨床外科医にとっても身につけなければいけないテクニックと成りつつあるが，血管走 行異常などにより困難な場合も多い.

今回紹介した超選択的肝動脈择管法は，滑りのいいガイドワイヤーと高カロリー輸液 用カテーテルを組合せて行う手技で, 昭和62年 1 月より昭和62年12月までの 1 年間に, 75例の肝癌ならびにその题いの患者にこの手技を施行した。いずれの症例も総肝動脈以 上の選択的肝動脈捜管を目標とし，失敗症例は 1 例のみであった．また，この期間に経 皮的に肝動脈カテーテル留置を行った症例は, 左鎖骨下動脈よりのアプローチで 7 例, 大腿動脈上りのアプローチで4 例で, いずれも皮下埋め込み式りザーバーと接続し，抗 癌剤 one shot 動注を行った。 紹介の超選択的肝動脈插管法は, きわめて安全, 容易な手 技と思われる。

索引用語：超選択的肝動脈插管法, 肝癌治療

はじめに

超選択的肝動脈插管のテクンックは, 肝癌の診断能 の向上をむたらすのみならず，抗癌剤の動注や transcatheter arterial embolization（TAE）などの治療面 に対しても有効で1 3), 習得すべきテクニックの1つ となっている。より正確な診断, 効率の良い治療目的 には, 肝癌病巣の支配動脈に，より選択的にカテーテ ルを進めることが必要であるが，実際には血管走行の 異常，血管孪縮，損傷などの理由でなかなか困難な場 合が多く，これを成しえるには熟練したテクニックと 患者側のかなりの忍耐が必要なように思われる.

今回考案した滑りのいいかイドワイヤーと高カ口 リー輸液用カテーテルを組合せて行ら，カテーテル交 換法による超選択的血管捰管法は，きわめて容易で， しかも安全, 確実な方法と思われるので紹介したい. また，肝癌の集学的治療の 1 つとて，透視下に左

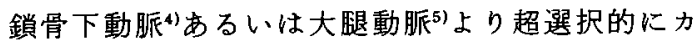
テーテルを肝動脈に留置し, 抗癌剤の持続動注, one shot 動注に使用しているのでその際のカテーテル留 置手技についても併せて紹介する.

1988年 5 月 10 日受付 1989 年 1 月 10 日採用

\section{方法}

\section{1. 使用する材料}

従来より使い慣れたカテーテルシースと腹腔動脈造 影用カテーテルのほかに, Terumo 社製の Radifocus guidewire M (以下, Radifocusとする)と Toray 社 製の高カロリー輸液用 Anthron heparinized catheter (以下, Anthron catheter とする) を使用する.

Radifocusは, アングル型, 外径 $0.89 \mathrm{~mm}$, 全長 150 $\mathrm{cm}$ を通常使用しているが, 血管走行, 太さにより時に ストレート型，外径の細い物を使用する場合むある. このガイドワイヤーは, 超弾性合金のコアをボリウレ タンで被覆し，さらに親水性ポリマーでューティング したるのであるが，従来のガイドワイヤーにくらべ柔 軟性が高く, 表面が平滑な上，生理食塩水や血液で需 れると優れた潤滑性を持つといら特徴を有する。

Anthron catheter は, 本来高力ロリー輸液用で外径 $14 \mathrm{G}$, 長さ $70 \mathrm{~cm} の$ あのを使用している.このカテーテ ルは, 塩化ビニールチューブの内外面をへパリン化親 水性材料でューティングしたものであるが，従来の血 管造影カテーテルにくらべ，長期に抗血栓性効果があ ること，柔軟で滑りがいいことなどで優れている。

また，插管したカテーテルを皮下に埋没し化学療法 
に用いる場合は、ニプロ医工社製の catheter access： CAS-103 (以下, catheter access) を使用している. これは，ステンレススティール製のリザーバー部分と シリコンゴム製のカテーテル部分よりなり，カテーテ ル部分は開腹して埋め込む以外に，コネクターにより 他のカテーテルとの接続が可能になっている.

\section{2. 捜管経路と操作手順}

超選択的肝動脈捜管経路としては，一般に行われて いる Seldinger 法による大䭆動脈よりアプローチする 方法とカテーテル留置を目的に左鎖骨下動脈よりアプ

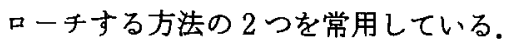

（1）大腿動脈よクのアプローチ（図 1)

A. Seldinger 法にもとづき，カテーテルシースを大 腿動脈内に留置しこれょり使い慣れた造影用カテー テルを挿入し，通常の腹腔動脈造影を行う。

B. この造影像を vascular map として,カテーテル を血管の根部に置いたまま, Radifocusを挿入し,これ を手元で先端のフングルを回転させながら㧌管目的の 血管の末梢に誘導する。

C. 誘導した Radifocusの先端が抜けないように透 視にて確認しながら，造影カテーテルを拔去する、

D. Radifocus 9 血管外露出部を生食ガーゼで十分 に拭い，滑りの良い状態とし，内腔を生食水で満たし た Anthron catheterを Radifocusにそって挿入す る. Radifocus は, 先端が動かない上5に手元でしっか り固定し，この潤滑性を利用して挿入する。血管の弯 曲部通過時には，Radifocus を僅かに手元に引くよう にしながら Anthron catheterを送り込む。

E. Radifocusを透視下に丁㸘に拔去する。
F，造影剂を注入しながら診断，治療に最適な部位 まで Anthron catheterを拔去する。

大腿動脈よりのアプローチでカテーテルを留置する 場合は，あらかじめ鼡径勒帯より約 $5 \mathrm{~cm}$ 末梢の大腿動 脈前面に皮䖒切開を拉き，動脈を露出してから，カテー テルシースを挿入する．カテーテルの留置が終了して カテーテルシースを拔去する時に，固定と止血を目的 に大腿動脈の穿刺部位を血管縫合系にて縫縮する。 カ テーテルは,一期的に catheter access と接続する場合 と，カテーテルの逸脱がないことを確認してから接続 する場合がある。

（2）左鎖骨下動脈よりのアプローチ（図 2）

A，左鎖骨中線上で鎖骨下縁上り $1 \mathrm{~cm}$ 下方上り皮唐 割線に沿って外側に，約 $5 \mathrm{~cm}$ の皮庼切開を扔く．皮下 脂肪組織，大胸筋，小胸筋を純的に剥離し，血管床の 中で動脈の拍動を目標に鎖骨下動脈を検索する．神経 叢の損傷に注意しながら左鎖骨下動脈の剝離を末梢中 权側に進め，その分枝である胸肩峰動脈または外側胸 動脈を搜し剥離する。

B．剥離した動脈分枝の鎖骨下動脈合流部の中权と 末梢にて鎖骨下動脈にテーピングする．これは以後の 操作に拈ける不意の血管損傷，出血に対処できるよう にするためのるのである.分枝血管の末梢側を結禁し， 外側に牽引しながら針先を中权側に向けて分枝血管を 穿刺し，カテーテルシースを挿入する。

C.これより Radifocusを乗入すると通常左心室に 達するので，これを先端が弯曲している誘導用カテー テル（通常，使い慣れた腹腔動脈造影カテーテルでい い）で下行大動脈に導き，カテーテルを下行大動脈に
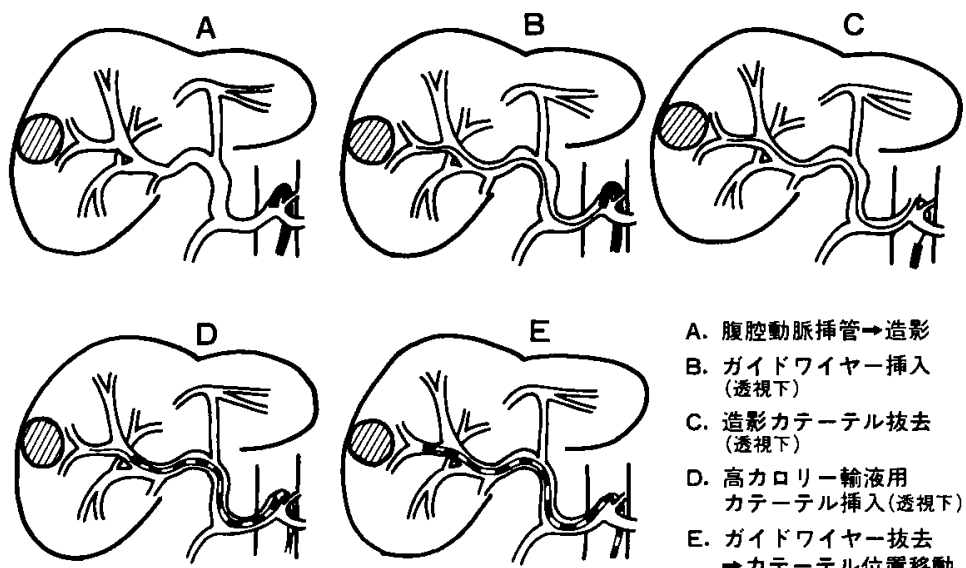
A. 腹腔動脈㨉管 $\rightarrow$ 造影
B. ガイドワイヤー㨂入 (透視下)
C. 造影カテーテル抜去 (透視下)
D. 高カロリー输液用 カテーテル择入(透視下)
E. カイドワイヤー抜去 カカテーテル位㯰移動

図 1 大腿動脈よりのアプローチ：カテーテル交換手技 

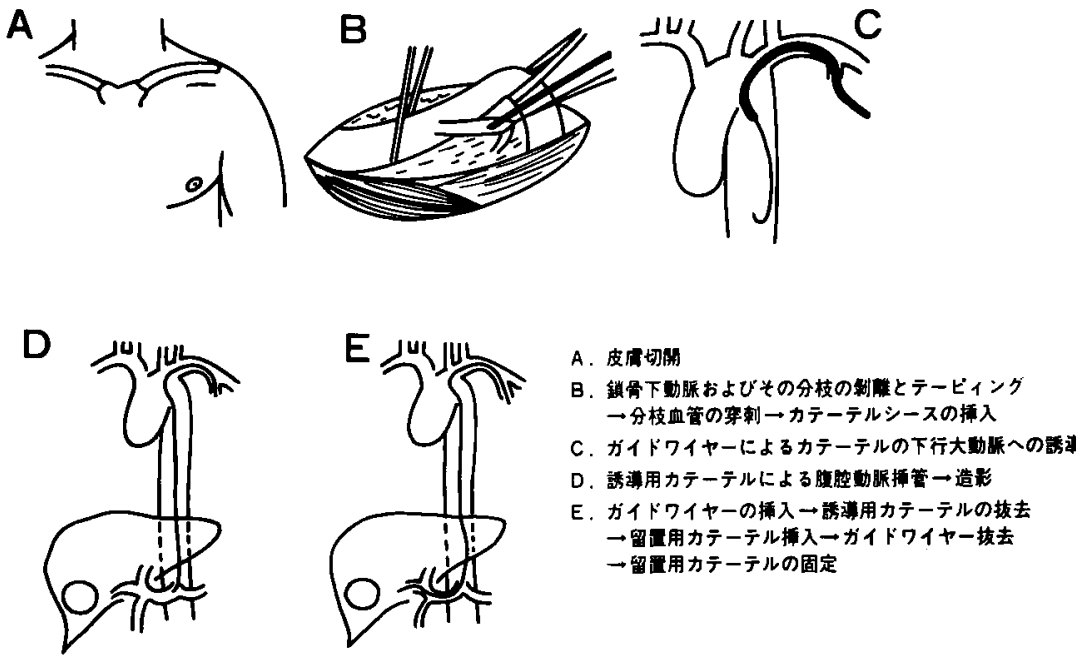

図2 左鎖骨下動脈よりのアプローチ

進める。

D.これより以後の操作は，前述した大腿動脈より 超選択的血管内插管の手技と同様である。留置用力 テーテルとしては Anthron catheter 使用している.

E．カテーテルシースを丁寧に抜去し，カテーテル が插入されている分枝血管をカテーテル内腔が保たれ るよらに結禁する。一期的または二期的に catheter access と接続する。

\section{成績および症例}

昭和 62 年 1 月より昭和 62 年 12 月までの 1 年間に, こ の方法で総肝動脈以上の選択的肝動脈掩管を行った原 発性肝癌, 転移性肝癌ならびにその疑いの患者は75例 であった。このらちカテーテル留置を行った症例は, 左鎖骨下動脈上りのアプローチで 7 例, 大腿動脈より のアプローチで 4 例で, いずれる one shot 動注が可能 のように catheter access と接続した.これら症例のう
ち右肝動脈が上腸間膜動脈より分枝する (replaced right hepatic artery）症例は 9 例（12\%）で，全例に 超選択的插管を試み，全例で成功した。

残りの66例の固有肝動脈は，腹腔動脈より分枝して 括り，このうち目的血管に插管し得なかった症例は， 固有肝動脈㨉管を試み失敗した 1 例のみであった。腹 腔動脈の走行抗よび分枝形式を安藤らの分類6ににした がって検討すると，(A) ほぼ水平に右方に向からすの 47例のなかで, (A)-1 固有肝動脈が総肝動脈から鈍角 的に分枝するもの 20 例，(A)-2 鋭角的に分枝するもの 14例，(A)-3 総肝動脈が頭側に凸の弓状をなすすの 7 例，(A)-4 左右肝動脈が総肝動脈上り別個に分枝する もの 4 例，(A)-5 総肝動脈が著しく屈曲しているすの 2 例で，(B) 頭側に向からむの12例，(C) 尾側に向か らもの 7 例であり, 各群に批る選択的挿管の成功率 は，表 1 のごとくであった。

表 1 肝動脈分岐形式（安藤 ( $^{6)}$ ) と超選択的肝動脈挿管の成功率

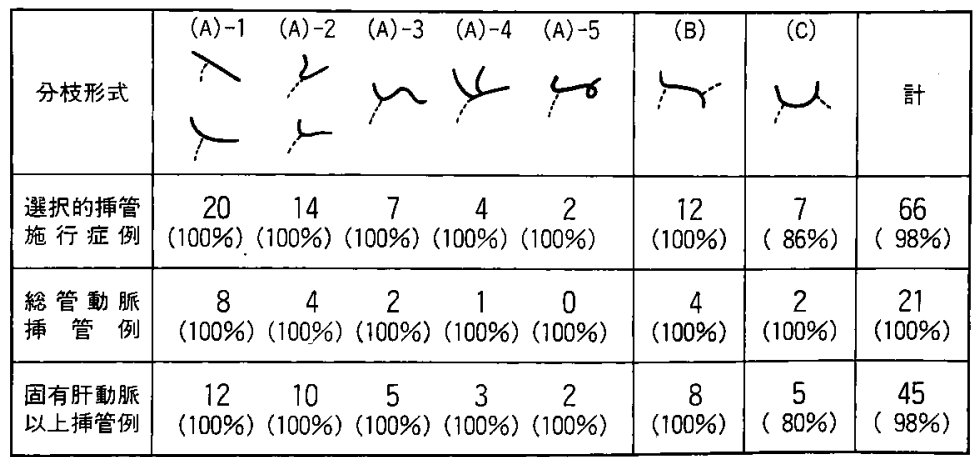


以下，紹介したカテーテル交換による手技を用いた 症例を供覧する。

症例 1．肝右葉より発生した肝細胞癌で右肝静脈よ り下大静脈, 右心房におよぶ腫瑒栓を認めた。肝動脈 の分枝形式は, (A)-1型であった。右肝動脈の選択的造 影後, この位置で抗癌剤とェマルジョンしたリピオ ドール10mlを注入した。 3 週間後に再度, カテーテル
を右葉後区域まで進め，造影したところ前回描出し得 た腫晹栓に流れ込む血管は認められなかった（図 3A， B).

症例 2.20歳の女性の右葉に発生した肝細胞癌で切 除肝重量は $2,000 \mathrm{~g}$ と巨大肝癌であった。腫瘍の圧迫に 上り腹腔動脈は屈曲, 変位しており, 分枝形式は(A)-5 とした，固有肝動脈までカテーテルを進め， degital

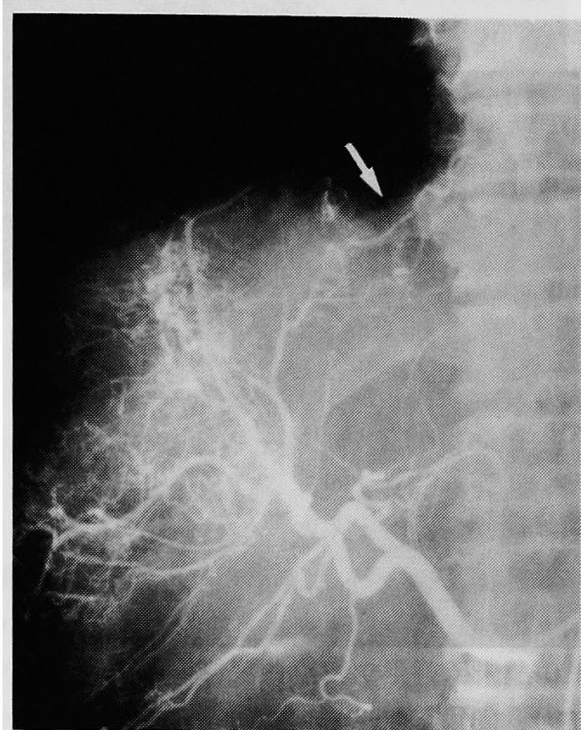

(A)

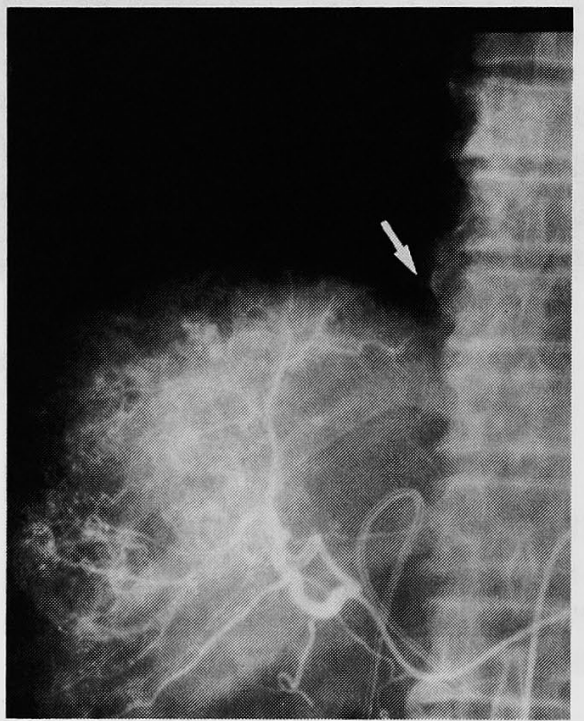

(B)

图 3 症例 1 の固有肝動脈造影（A）と右肝動脈啳区域の選択的造影（B）：矢印は，下大静 脈に続く腫痬栓血管を示寸。

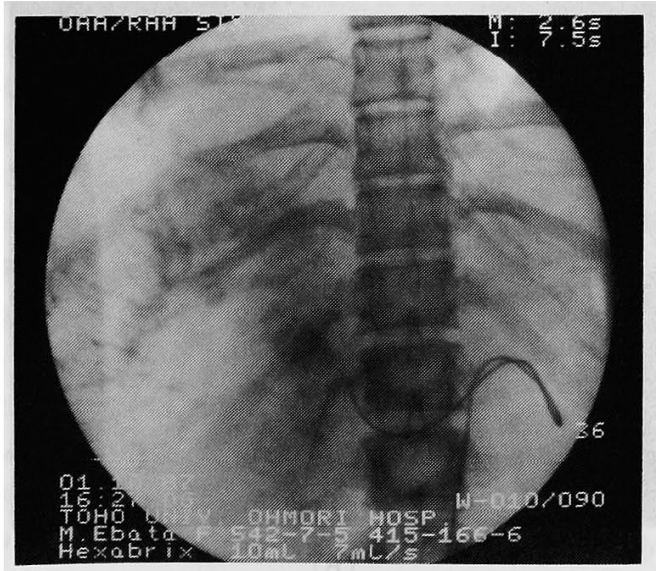

(A)

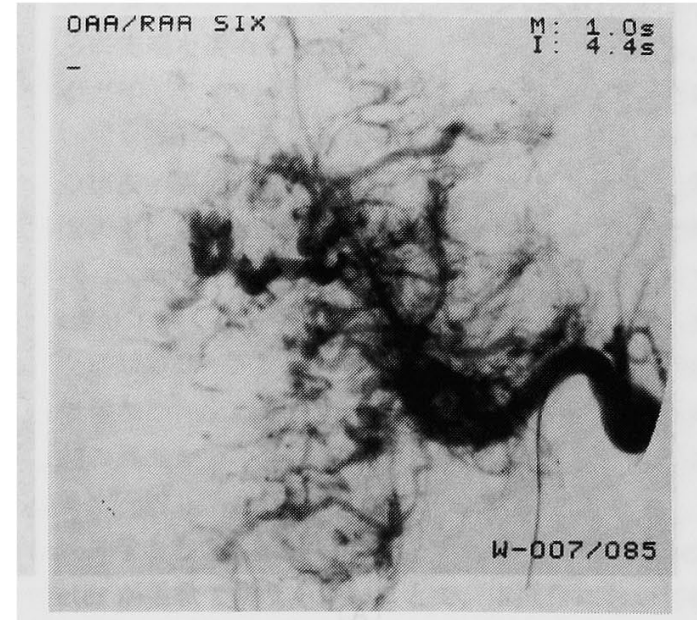

(B)

図 4 症例 2 のカテーテル挿入時写真 (A) と固有肝動脈造影 (B)：巨大董瘍により腹部大 動脈，腹腔動脈ともに左方に変位し，屈曲している。新生血管の増加が著明であった。 
angiographyを行った（図 4A,B）。

症例 3. 腹部大動脈の屈曲をともなった76歳の胆裂 癌症例で, 肝内浸潤, 肝内転移を認めた。肝動脈の分 枝形式は(B)型であった. 腹腔動脈造影後, Radifocus を固有肝動脈に進め, 造影後 lipiodolizationを行っ た.腹腔動脈插管に時間を要したが, 選択的カニュレー ションは容易であった（図 $5 A, B ）$.

症例 4 . 右後区域に発生した肝細胞癌症例で, 右肝
動脈は上腸間膜動脈より分枝していた．右肝動脈の選 択的造影, lipiodolizationにつづき, 左肝動脈の造影, lipiodolizationを行った（図 6A, B).

症例 5 . 直腸癌の肝転移症例で, 3 年前と半年前に 肝切除を行った。残肝再発に対し，左鎖骨下動脈より のアプローチによりカニュレーションを試みた，施行 前のTAEにより腫瘍血流は, 右横隔膜動脈におきか わって拈りここれにカニュレーションした(図 7A, B).

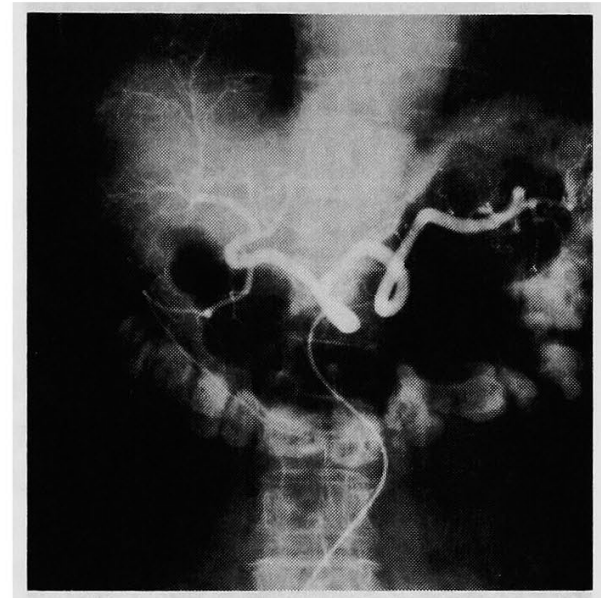

(A)

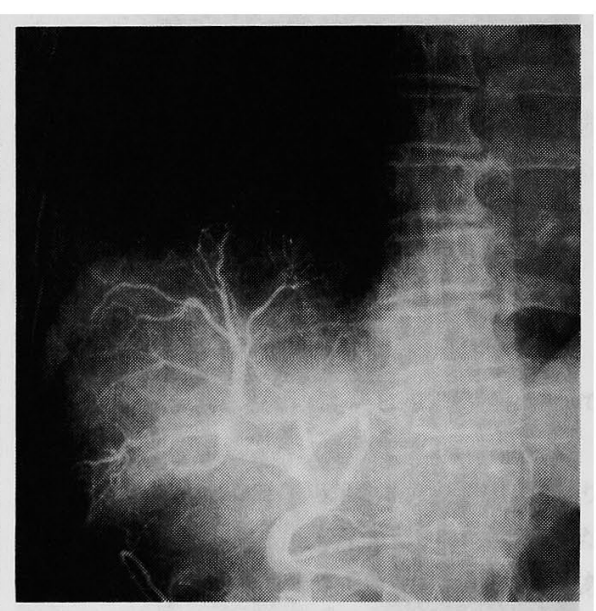

(B)

図 5 症例 3 の腹腔動脈造影 (A) と固有肝動脈 (B)：カテーテル走行より腹部大動 脈の屈曲の程度が想像できる、胆轰動脈の抎張と途絶を認めた。

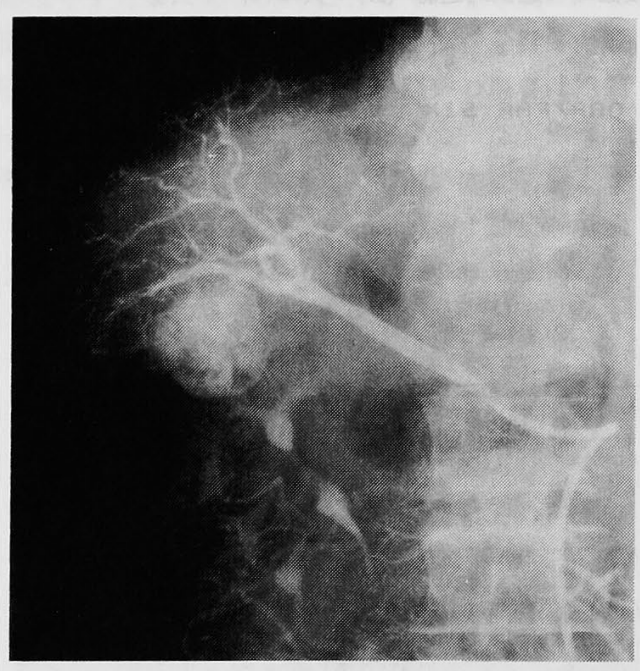

(A)

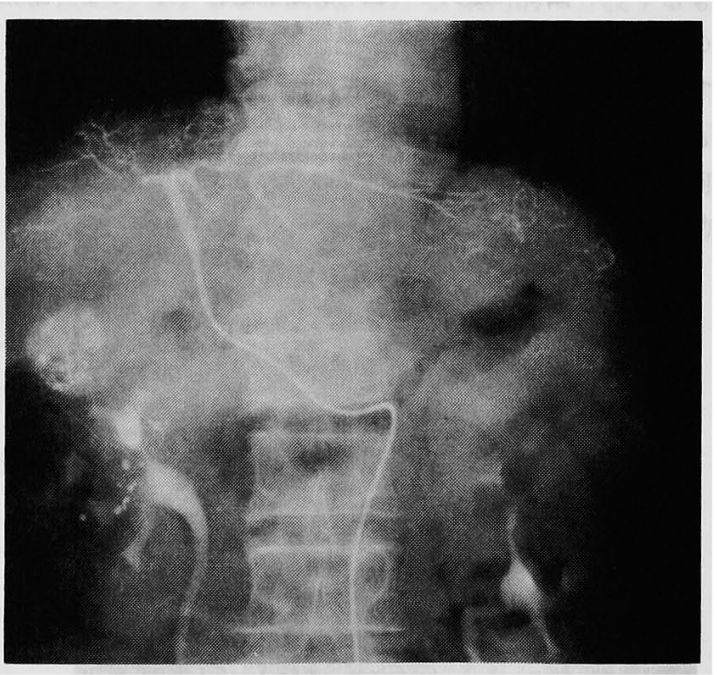

(B)

図 6 症例 4 の右肝動脈造影 (A) と左肝動脈造影 (B)：上腸間膜動脈より分枝して いる右肝動脈造影に続き, 腹腔動脈より分枝している左肝動脈造影を行った. 左右 肝動脈に lipiodolization を行った。 


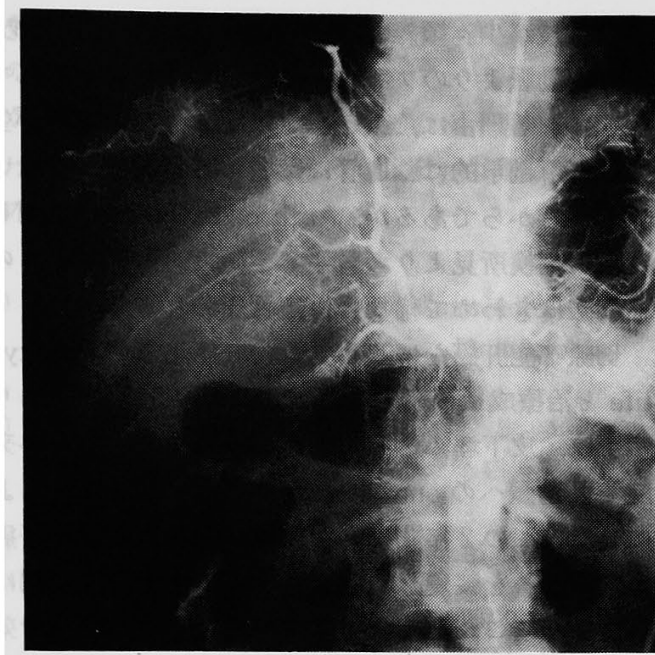

(A)

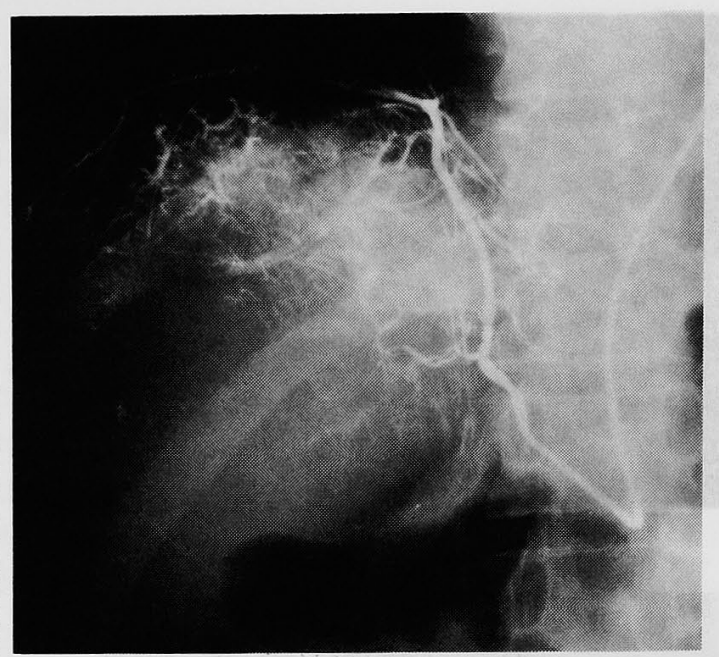

(B)

図 7 症例 5 の右横隔膜動脈と左胃動脈造影（A）と選択的右肝動脈造影（B)：左鎖 骨下動脈よりのアブローチで右横隔膜動脈に選択的插管を行った。腫瘍の栄稂血管 が描出された。

症例 6 . 肝内に多数の病変を認める肝細胞癌症例 で，肝動脈の分枝形式は (C) 型であった，大腿動脈よ りのアプローチで, 腹腔動脈造影後, 固有肝動脈カニニ レーションを試みたが，初期の症例で手技が未熟で あったせいか失敗した。日を改めて，左鎖骨下動脈よ りアプローチしたが，このときは容易に固有肝動脈に 㨀管し得た（図 8A, B）.

\section{考察}

細小肝湂の存在および部位診断, TAEをはじめ上 する経カテーテル治療の普及とともに超選択的に肝動 脈に插管する手技は欠かせないテクニックとなりつつ

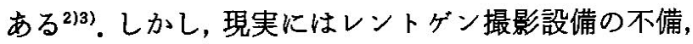
肝動脈走行の多様性, 血管挛縮および内膜損傷の併発, 長時間にわたる患者の身体的精神的負担なとにより本 来目的とした血管までのカテーテル到達が困難な症例 む多いよらに感じる。

超選択的血管造影の手技についての報告は数多くみ られ，その代表的なあのとしては，先端が特殊に屈曲 したカテーテルを用いる方法6) 9), 二重管法 ${ }^{112)}$, カテー テル交換法199，ガイドワイヤーを先行させる方

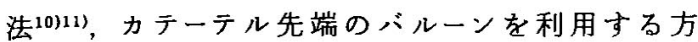
法 $^{12) 13)}$ ，上記のいくつかを組合せる方法8) 10)などであ るが，いずれの手技すある程度の熟練を要するように 思う。これらにくらべると，今回紹介した方法は，滑 りのいいRadifocus と高力ロリー輸液用の Anthron catheter を組み合せて行うカテーテル交換による血

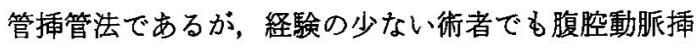
管が可能なら, 短時間に, しか子安全に固有肝動脈以 上の超選択的㨀管が可能で, きわめて有用な方法と思 われる。

超選択的訮動脈搟管がこれほど容易になった理由と しては，第 1 に Radifocus の柔軟性と表面平滑性，潤 滑性がすぐれていることがあげられ，このため血管内 膜の損傷が少なく，ガイドワイヤーを末梢分枝まで容 易に先端を進めることが可能となったことである。こ のガイドワイヤーは，カテーテルを交換する場合にお いてもカテーテルとの摩擦抵抗が小さく，カテーテル の抜去, 再摷入の操作がスムーズで,このため先端の 逸脱もほとんど生じない.しかし，Radifocus 操作時に は，ありりを容易に微細血管に挿管されるため, vascular mapをめやすに十分な注意をはらいながら先端 を進めることが必要で，この方法を開始した初期に， 無理な操作を行ったために，幸いにも根治手術時に血 腫の形成を認めただけであったが，カテーテルが血管 外に逸脱した症例を 1 例経験している.

插管が容易になった第 2 の理由は, Anthron catheter が柔軟で滑りがいいことで，本操作に拈いては， Radifocus が目的血管の末梢まで挿入されていれば， まずカテーテルを再插入する際にカテーテルが逸脱す ることはなく，血管壁の損傷，血管攀縮的経験してい 


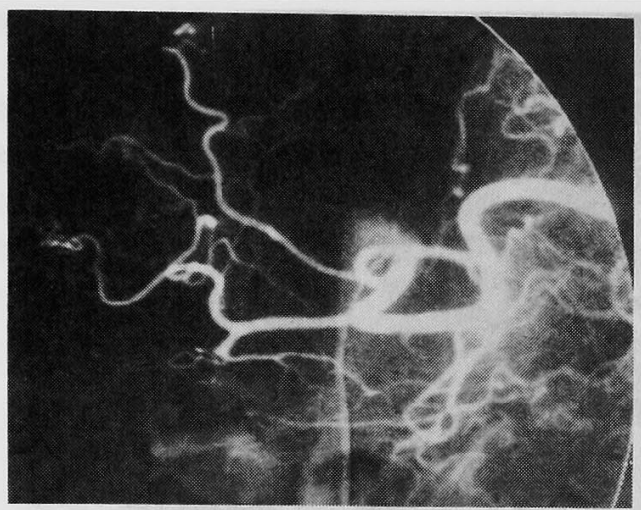

(A)

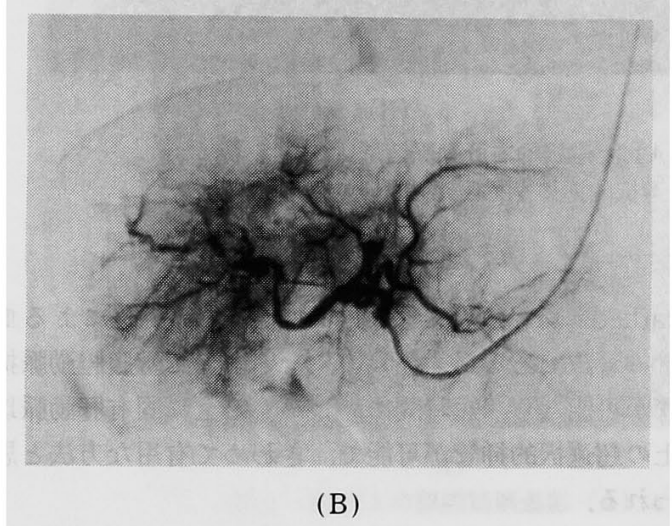

図 8 症例 6 の腹腔動脈造影（A）と固有肝動脈造影 (B)：右大䭆動脈よりのアプローチにて固有肝動脈 挿管を試みたが，捙管不可能であった，左鎖骨下動 脈よりの固有肝動脈插管は容易で, 肝内に多数の腫 瘍濃染像を認めた。

ない.また，カテーテルの長期留置に際しても，抗血 栓性効果があること，大腿動脈，左鎖骨下動脈いずれ のアプローチでのカテーテル留置に执いても適度の柔 軟性のために血管壁の内膜損傷，カテーテル逸脱が少 ないことなとで優れていると思われる。

今回紹介した左鎖骨下動脈扣よび大腿動脈より超選 択的に肝動脈に挿管してカテーテルを留置する手技 は，必ずしも血管連続撮影装置が必要なわけでなく， 前述した材料と消化管透視の装置があれば，どの施設 でも十分に実行か゚可能な手技と思われる．左鎖骨下動 脈よりアプローチする手技は, 大腿動脈よりのアプ ローチにくらべ血流に順行性の部分が多く，また体動 によるカテーテルの動きも少ないため，カテーテルの 逸脱は少ない.しかし，大腿動脈よりのものにくらべ
ると手技が少々煩雑で,カテーテル操作も困難である. 鎖骨下動脈よりのアプローチで，右より左を好んで選 択している理由は，カテーテルよりの血栓剥離が生じ た際に解剖学的に脳血管に影響する可能性が少ないと 思われるからであるが，Anthron catheter を使用した 症例の剖検所見より考慮すると,カテーテルよりの血 栓剝離はきわめて稀な合併症と思われる。

切除不能肝癌をはじめとした肝癌患者の quality of life と治療成績の向上を目的に，昭和 61 年 2 月上り教 室では，皮下埋め込み式リザーパーを導入し，外来通 院で肝動脈への one shot 動注が繰り返し行えるよう にした.この 2 年間に開腹搟管例を含さ32例の肝癌患 者で，これを装着し現在経過観察中である。長期に合 併症なしにこれを維持する工夫とともに，安全で効率 い抗癌剤の選択, 抗癌剤の他葴器に対する副作用の 軽減や腫瘍内抗癌剂濃度を高める血行改変術の工夫か; 今後とも必要と思わわれる(14)15).

今回の報告は訮動脈領域を中心に述べたが, Radifocus guide wire $M$ と塩化ビニール性高カ口 リー輸液用カテーテルを組合せた手技の応用範囲は広 く，骨盤内出血，消化管出血などに対する救急止血操 作, 肝胆道系や尿路系の閉塞における内瘦化 ${ }^{16)} と ゙$ 多 葴器にわたって有用と思われる。

$$
\text { まとめ }
$$

肝動脈に超選択的に挿管する手技として, Radifocus guidewire $M と$ Anthron heparinized catheter(高カロリー輸液用)の組合せによるカテーテ ル交換にもとづく方法を紹介した。この方法の長所と しては,

1)より選択的な肝動脈插管が可能である.

2）短時間で挿管可能で, 患者, 術者とも放射線被爆 が少なく，精神的負担も少ない。

3）初心者でも超選択的插管が可能である.

4）血管の内膜損傷，血管挛縮などの合併症が少な い.

5)特殊材料が必要なく，安価である。 などで，短所としては，

1）がイドワイヤーの滑りが良すぎてガイドワイ ヤー操作が思5ようにいかない.

2）ガイドワイヤーによる微細血管損傷の可能性が ある。

3）カテーテル入れ替え操作が煩雑なため,ある程度 なれるまで助手が必要であることが多い。 などである。 
カテーテルの長期間留置手技として, 左鎖骨下動脈 よりのアプローチ, 大腿動脈よりのアプローチを紹介 したが、これを catheter accessなどの皮下埋め込み式 リザーバーと接続し肝癌患者の quality of life と治療 成績の向上をはかりたい。

\section{文献}

1) Reuter SR, Redman HC: Gastrointestinal Angiography. 2nd ed. Saunders, Philadelphia, 1977, p11

2）鈴木 敞, 川部克已：腹部外科と血管造影 V. 撮 影法の改良と動脈カテーテル法による癌治療. 臨 外 $26: 805-815,1971$

3）山田龍作：肝細胞癌に対する transcatheter arterial embolization therapy の経験, 脈管学 18 : $563-571,1978$

4) 荒井保明, 木戸長一郎, 太田和雄他：皮下埋め迈及 式リザーバー使用による動注化学療法。臨床60例 の検討と新しい薬凧投与法への可能性. 第 1 報. 技 術面について, 癌と化療 $12: 270-277,1985$

5) 太田 宏, 阿岸鉄三, 大場 忍他: 抗癌剂動注用植 え込々型カテーテルの留置法一開腹手術か血管造 影手技か, 癌と化療 $14: 2359-2363,1987$

6) 安藤啓次郎, 児玉隆浩, 沖田 極他：超選択的肝動 脈造影用の新しいカテーテル twist catheter の考 案之使用経験, 肝臓 $21: 999-1007,1980$

7) 三品寿雄, 高橋康幸, 鈴木 豊他：われわれの工夫 した double loop catheter による超選択的血管造 影, 臨放線 $22: 609-613,1977$
8）久保田化, 光島 徹, 大城宏之他：コフキシアルカ テーテルによる肝動脈塞栓術, 臨放線 $32 ： 455$ $-460,1987$

9）草野正一,村田晃一郎, 大内 寛他：選択的肝動脈 カテーテル挿入術の標準化 longtapered curved catheter 法, 日医放線会誌 $45: 807-820,1985$

10）山田龍作, 工藤弘明，奥山和夫他：われわれが考案 したスパーセレクターワイヤーの各種血管カテー テル術への応用，脈管学 $21: 55-62,1981$

11）沢田敏, 大澤太一，田中敬正：Ultrasuperselective hepatic angiographyに対する一工夫。 3Fr. バルーン・カテーテル・ガイドの応用, 臨放 線 $30: 731-733,1985$

12）松尾賢二，鈴木 誠，大村一夫他：Balloon カテー テルを応用した超選択的血管造影法について, 脈 管学 21:401-407, 1981

13）中村仁信, 大井博道, 田中真理子他：バルーンカ テーテルを利用した肝動脈塞栓術, 臨放線 30 ： $469-473,1985$

14）荒井保明，木戸長一郎，遠藤登喜子他：転移性肝癌 に対するFAM 動注化学療法 (Phase II study) Preliminary report, 癌と化療 14:2327-2333, 1987

15）荒井保明, 木戸長一郎：間歇的少量反復動注法, 癌 々化療 $12: 1922-1929,1985$

16）鈴木治, 川村㤵二, 山口智正他：尿路に打けるテ ルモ社製ガイドワイヤーの使用経験, 泌尿紀要 $33: 638-643,1987$

\title{
DEVICES FOR SUPERSELECTIVE HEPATIC ANGIOGRAPHY AND HEPATIC ARTERIAL CANNULATION
}

\author{
Masashi WATANABE, Toshimichi MAEDA, Haruhiro NAKAZAKI, Hidetoshi HABA, \\ Shintaro KURAMOTO and Toshifumi YOSHIO \\ First Department of Surgery, Toho University School of Medicine
}

For accurate diagnosis and therapy of hepatic cancer, superselective angiography and hepatic arterial cannulation are the techniques that must be acquired by clinical surgeons, though it is quite often difficut to perform due to the variation of vascular distribution.

The superselective hepatic arterial cannulation can be performed by employing a smooth sliding guide wire and a catheter that is usually used for the intravenous hyperalimentation.

Between January 1987 and December 1987, we carried out this technique on the 75 patients diagnosed as hepatic cancer or heaptic cancer suspect. Not only the common hepatic cannulation but also the selective hepatic cannulation are aimed in each case. And we only failed in one case. During this period, percutaneous catheterization into the hepatic arterey was carried out in 7 patients with left subclavian arterial approach and in 4 patients with femoral arterial approach. All catheters were connected with intersubcutaneous reservers, and intra-arterial one shot chemotherapy was given through them.

It is concluded that the superselective hepatic arterial cannulation is a very safe and easy technique. 